\title{
Do Heterodox Theories Have Anything in Common? A Post-Keynesian Point of View
}

\author{
Marc Lavoie*
}

The paper questions the wide-spread assertion that non-orthodox schools of thought in economics have only one thing in common - their rejection of mainstream (neoclassical) economics. The author shows by contrast that heterodox currents share some fundamental analytical insights. The paper focuses on a comparison of modern Marxist conceptions with those of Post-Keynesian economists, including the works of Kaleckians and Sraffians. This is shown by examining four fields: the issue of rationality (where the adjustment principle is explicitly accepted by important heterodox authors), price theory (with cost-plus pricing combined to some long-run adjustment), growth theory (where the Kaleckian model has been adopted by authors from all schools), and finally monetary theory (where authors from all backgrounds are successfully integrating real and monetary analysis by taking into account financial markets). The author concludes that mutual feedback between the various heterodox currents has been beneficial to all, despite an unavoidable hyper-specialisation.

JEL classification: BS

Keywords: heterodox schools, coherence, procedural rationality, cost-plus pricing, effective demand, integration of money

* University of Ottawa. The article, which was translated from French by Catherine Leviten-Reid, is based on a presentation that was made at the Hétérodoxies MATISSE workshop, on December I4, 2004, at the University of Paris I. I am very grateful to Bruno Tinel and Liêm Hoang-Ngoc for having organised my visit there. I am also grateful to Eckhard Hein for having suggested to have an English version published in INTERvENTION and to Torsten Niechoj for having arranged the translation. I also wish to express my thanks to the two referees of the journal. A very slightly different version is scheduled to appear in Spanish in the Colombian journal Lecturas de Economia, and has been published in French as "Les théories hétérodoxes ont-elles quelque chose en commun? Un point de vue post-keynésien", in: Économies et Sociétés, Vol. 36, No. 6, 2005, pp. I09I-II24.

Correspondence address:

Prof. Marc Lavoie, University of Ottawa, Department of Economics, 200 Wilbrod Street, Ottawa, Ontario, KIN 6N5, Canada, e-mail: marc.lavoie@uottawa.ca

Received 3 May 2005, accepted 30 Sep 2005

(C) Intervention. Journal of Economics, Vol. 3 (2006), No. 1, pp. 87-112 


\section{Introduction}

It is sometimes claimed that heterodox economists have nothing in common but their rejection of neoclassical theory - mainstream economics. The same could be true for one of the groups that make up heterodox economics, namely Post-Keynesians. Is this negative perception of heterodoxy really justified? Do the numerous heterodox schools of thought within economics have something in common? If so, what is it that links Marxist economists, Sraffians (or neo-Ricardians), structuralists (in development economics), institutionalists, regulationists, social or humanist economists, anti-utilitarists, behaviourists, economists of conventions, Schumpeterians (or evolutionary economists), circuitists, feminist economists and many others? What are the common elements of the different components within the Post-Keynesian school, namely the fundamentalist Keynesians, the Kaleckians and the Sraffians?

Heterodox schools are subjected to the influence of two opposing forces. On the one hand, they are prone to the overall divisions which occur in the sciences and in economics in particular. Here, each school has a tendency to specialise in the study of particular questions and tries to distinguish itself from the others. So at the same time as being complementary, these diverse heterodoxies are rivals, each one focusing its analyses on a particular aspect of the economic field. This divisive tendency is reinforced by the behaviour of some researchers who need to differentiate their work at all costs or who very much need to exclusively validate their own ideas. Moreover, as Andreff (1996) has pointed out, heterodox writers have a tendency to practice scientific agnosticism, which leads them to take issue with whatever ideas may be put forward, especially those from rival schools. This makes efforts to unify the different schools difficult to imagine.

But a counter tendency also exists which is caused, perhaps, by a situation in which minorities are in peril. Some heterodox researchers from different schools have been prompted to advocate for interactions and to take steps to bring the different schools together. This is particularly the case among US-American Post-Keynesians and Radicals (Marxists) in macroeconomics and monetary economics. In fact, one organisation, the International Confederation of Associations for Pluralism in Economics (ICAPE), regroups all heterodoxies and their institutions or journals. The existence of a seminar called "Heterodoxies" at the MATISSE (Modélisation Appliquée Trajectoires Institutionnelles Stratégies SocioEconomiques) is also perhaps a symbol of the necessity of building relationships between these schools. In addition, Steve Fleetwood, at the Institute for Advanced Studies at the University of Lancaster (England), has launched an ambitious program, the objective of which is to generate more intellectual exchange between heterodox economists of different schools of thought.

As for me, I have always believed that heterodox economists had a number of things in common and shared numerous concepts, even if for very specific questions they could have quite diverging and distinct opinions. It seems to me that this is the lot of all economists, including neoclassical ones. It is normal that, even when sharing the same method or overall vision, individuals disagree on certain questions. Otherwise, they would no longer be individualss. 
Critique is an absolute necessity in science and in economics. It allows us to correct errors, modify and improve our concepts, and incorporate factors that were wrongly omitted. But while criticising rival heterodox abstractions or models, heterodox economists should never forget that they have more in common with other heterodox colleagues than with most authors of the neoclassical school. Petty quarrels on trivial issues between clans and between those who are leaders of different schools of thought will never lead heterodox economics anywhere, and they are extremely destructive to the heterodox economics movement. They prevent the development of institutions and organisations that regroup and strengthen isolated researchers or research groups. We have to demonstrate a certain detachment from the ideas we have proposed and defended. We have to recognise the relevance of work that adopts approaches or formalisations different from the kinds we would have chosen.

To counter the possibility of some coherence or synergy among heterodox schools of thought, some of my colleagues fall back on the writings of the founders to assert that, for example, the Kaleckian school is incompatible with the Sraffian school or the fundamentalist Keynesian school, by arguing that some paragraph written by Keynes, Kalecki, Marx or Sraffa is contrary to the ideas expressed by one or another of the founders. As interesting as the works of these researchers are, what is pertinent is how we use them today and how contemporary economists integrate their ideas and put them forward. The question that should be asked is not whether Keynes found Marx's work interesting or meaningless, but whether the writings of our Post-Keynesian and Marxist contemporaries show some cohesiveness.

The objective of this essay is to counter the tendency to isolate each school or group of researchers from others with similar leanings. The most startling example of such behaviour can be found in the recent article by Paul Davidson (2003-04), the editor of the Journal of Post Keynesian Economics (JPKE) and consequently one of the leaders of the PostKeynesian school. ${ }^{I}$ In the article, Davidson reviews the history of Post-Keynesian theory according to a book written by John King (2002), a Keynesian who became a Marxist, then, finally, a Post-Keynesian. Davidson does three things: he criticises King for using an incorrect definition of the term `Post-Keynesian`, he claims that neoclassical economists rejected the contributions of >Post-Keynesians because this school of thought was too heterogeneous and lacked coherence, and finally, he identifies what he thinks were the axioms and the people who are part of a true >Post-Keynesian` school.

King (2002) uses, albeit implicitly, definitions suggested by Davidson himself 20 or 30 years ago (Davidson 1972, I981, 1982): the term Post-Keynesian was thus used in a broad sense and encompassed as much the contributions of American Post-Keynesians à la Davidson and Weintraub as those of Italo-Cambridge authors, Marxist-Keynesian authors (such as Galbraith or Sweezy), and certain economists of neoclassical persuasion that were close to Keynes, like Tobin and Hicks. A similar definition was provided by Hamouda and Harcourt (1988). According to these authors, the Post-Keynesian school was divided into 
three large groups: neo-Ricardians (Sraffians), Kaleckians, and Marshallians (fundamentalist Keynesians). According to Davidson (2003-04), this broad definition is wrong: the only true `Post-Keynesians` are, using Davidson's expression, fundamentalist Keynesians, meaning those whose analyses are based on the theoretical structure laid out by Keynes in the General Theory. This means his Marshallian analysis, his monetary theory of the rate of interest, his explanation of unemployment based on liquidity and monetary characteristics and, finally, his notion of uncertainty.

This leads Davidson to explain in great detail that Kaleckians and Sraffians should be excluded from the Post-Keynesian school as thus defined. This also leads Davidson to excommunicate two people whom some consider to be the pillars of the Post-Keynesian school, his fellow US-Americans Hyman Minsky and Alfred Eichner (both of whom Davidson considers to be closet New Keynesians). In fact, other than a few and less wellknown followers, Davidson includes only a minimum of authors in the Post-Keynesian school: Sidney Weintraub (his old mentor), Basil Moore (a long-time friend), Anthony Thirlwall (who looks like Keynes) and Nicholas Kaldor (one wonders why, since he was quite critical of many features of Keynes's General Theory, arguing that Kalecki's work provided better foundations). All the others are either omitted or expelled, including the most well-known of his former students, Jan Kregel. In a certain sense, none of this is very surprising. Davidson already showed some of his true colours during an interview with John King (1995), when already he wanted to challenge the usefulness of Sraffian and Kaleckian works. Moreover, in his 1994 book devoted to the definition of Post-Keynesian economics, Davidson cites only four of his Post-Keynesian contemporaries, omits Minsky from his index, and seems satisfied to cite the works of only the most seasoned neoclassical authors.

It seems clear enough to me that this type of sectarian behaviour or strategy is doomed to fail. Young readers of Davidson get the impression that he is the only worthy heterodox Keynesian, and that it is better to read the great neoclassical writers than other heterodox economists. His over-emphasis of the intellectual superiority of a single line of thought leads nowhere. Strength is found in numbers, even if the coalitions lack coherence or cohesion.

At the heart of the present paper is the belief that heterodox economists do have a lot in common, and the belief that heterodox economics goes well beyond the critique of mainstream economics. It is not necessary to try to imitate or compete with neoclassical economists on their own turf: heterodox economists do have their own turf and their own rules. The future of heterodox economics rests on the development of its own topics of analysis and on the choice of its own analytical tools. The snegative contribution of heterodox economics - especially the critique of hypotheses or methods used by neoclassical theorists - is something necessary and important. But heterodox schools cannot put all of their human resources, small in number compared to the neoclassical majority, into criticising theories about which they are generally not experts or into the study of the history of economic thought. An ever growing number of heterodox economists needs to provide a spositive contribution, by developing heterodox theories, gathering histori- 
cal facts or statistics that would be useful to the development of these alternative theories, and by devising empirical or econometric tests that would provide support for heterodox theories and improve their rhetoric. Finally, heterodox economists need to develop simplified versions of theories which would allow for their transformation into pedagogical tools. Nature hates a vacuum, and it is in filling these gaps that heterodox economists will encourage more young researchers to adopt alternative visions and theories and to teach them in their classrooms.

In the following text, I will try to establish linkages between the diverse heterodox schools, particularly those that deal with macroeconomics. To Post-Keynesians, I will compare the works of those who represent the French Regulation school and the classical, or Marxist, school. I believe I can demonstrate that all these works have a number of points in common, even if their conclusions sometimes diverge.

I will not review all of the writings of each heterodox school of thought. That would be an impossible task. Moreover, I would not be able to address all of the specialised fields. To illustrate my claim, I will tackle four representative themes: the concept of rationality, price theory, growth theory, and finally the link between the real and the monetary analyses of economics.

\section{Rationality}

In Lavoie (1992, I992b), I asserted that the distinctiveness of heterodox economics vis-àvis neoclassical economics rested on four pairs of presuppositions. These are: realism versus instrumentalism, organicism versus methodological individualism, production versus exchange, and procedural rationality versus substantive rationality. I still think that this way of looking at things is useful as long as these demarcations are not taken literally. Moreover, a number of heterodox thinkers adhere to these four presuppositions. ${ }^{2}$ I have since added a fifth, and political, pair, which distinguishes those who believe in the undeniable virtues of the free market from those who favour regulation and state intervention (Lavoie 2006).

I do not want to belabour these methodological questions. While I was comfortable doing so during the first debates in the I980s, discussions between methodologists seem to be increasingly hermetic to laymen. My positions stated above must also appear quite

2 This is surely the case for Post-Keynesians, as we can see in the readings of Setterfield (2003) and Pasinetti (2005). I also believe this to be the case for Duménil and Lévy (1993). In their chapter on mainstream microeconomic theory (chapter ten), the words srealism ‘ and sunrealistic appear a number of times. They also reproach the Neo-Walrasian production model for being nothing more than an extension of the pure exchange model, and they call for a procedural rationality based on the adjustment of observed disequilibria, as we will see later. Finally, they call for a class analysis which is compatible with the idea of organicism. 
rudimentary to specialists. ${ }^{3}$ Nonetheless, I would like to touch on the presupposition of rationality. Discussions with several heterodox colleagues have convinced me that this is a fundamental point that differentiates heterodox from neoclassical economists. Some could say it is actually an example of 'realism versus instrumentalism،. This is perhaps the case, but let us still discuss the presupposition of rationality. For neoclassical economists, rationality is absolute: economic agents have full information, or have the means of getting it, or they have the data needed to calculate the optimal amount of required information. Moreover, neoclassical agents are able to deal with all of the information they have. Here, we do not even discuss the question of rational expectations where, above and beyond the information agents have, they are also perfectly aware of how the economy functions, all agents sharing the same model or prototype that allows them to understand economic dynamics.

It is clear that Post-Keynesians reject such a view of rationality either, as Herbert Simon would say, because it is impossible for economic agents to deal with the (imperfect) information that they are able to acquire (epistemic uncertainty) or because the world is nonergodic. Agents find themselves swimming in full fundamental uncertainty, as Keynes, Shackle or Davidson would say, because the states of nature are uncertain (ontological uncertainty). The world is nothing but an open system that depends on the free choice of agents, who are also subjected to butterfly effects. Many works by Keynesian economists put forward this fundamental uncertainty and the bounded rationality associated therein. Other works, notably by those who are interested in consumer theory, bring out a procedural or ecological rationality. This is based on non-compensatory choices in which decisions are made quickly and centred on a limited number of criteria, without having to make complex calculations of all substitution possibilities at all times.

But what about the other heterodox economists? When I was asked to write a paper on consumer theory that would serve as a foundation for a theory of sustainable forestry economics, I recently discovered that heterodox economists in the environmental field (partisans of ecological economics) have been, for a good 20 years, proposing models of consumer behaviour that are very similar to those proposed by several economists of PostKeynesian influence. Steeped in the works of Galbraith and Georgescu-Roegen, these theories are essentially based on non-compensatory choices which cannot be represented by the usual neoclassical utility functions and which allow one to explain the paradoxes observed in contingent valuation studies of some environmental projects (Gowdy/Mayumi 200I, Lavoie 2005). ${ }^{4}$

3 The question of realism has been the object of several recent debates, notably through the impetus of Lawson (1997) and his approach to critical or transcendental realism. Relying on Maki's (1989) numerous definitions of realism, it seems that I am partial to >realisticness` and not >realism` properly defined.

4 In fact, I have also recently discovered that certain partisans of ecological economics demand that Sraffian prices be used to correctly assess the prices that should be charged to companies that use renewable resources. 
There is also a very illuminating paper by Duménil and Lévy (1995) that, in my opinion, clearly illustrates that procedural rationality is in fact a common presupposition among heterodox economists. During the debate about their 1993 book, Duménil and Lévy fiercely defend what they call the principle of adjustment in the face of the neoclassical principle of constrained optimization with rational expectations. This principle of adjustment is a specific modeling of Simon's procedural rationality. Duménil and Lévy (I995: 369) claim that agents are

"decentralized, in disequilibrium, hold limited information, do not know either the real model of the economy or the laws of the distribution of random variables or the characteristics of other agents. They are in an environment that is constantly changing and largely unpredictable, in other words, situated within >radical uncertainty.«

No Post-Keynesian could have said it any better!

Duménil and Lévy's words fit quite well the vision of a number of Post-Keynesian authors, many of whom have been keen on describing the evolution of an economy instead of making propositions about comparative statics. This is certainly the case for a Cambridge economist, Wynne Godley, a person with whom I have had the chance to collaborate. For Godley, like Duménil and Lévy (1995: 372),

"adjustment concerns all behaviour [.] [...] It can serve to describe the behaviour of an individual [,] [...] it applies to an institution, like a firm. We can also apply it to the banking system and the entire system that governs monetary policy."

It is also, at another level, a principle that applies to the French Regulation school: if a system no longer works, another system will progressively be put in place. For Godley, the principle of adjustment typically involves some target ratio. This ratio is generally a stockflow ratio, set by households, banks or firms, for instance an inventory to sales ratio in the case of the latter. Governments also give themselves target ratios, for instance deficitto-GDP or debt-to-GDP ratios.

In my 1992 book, I maintained that the rules of thumb or routines of economic agents or institutions were not ad hoc (Lavoie 1992: 6I). Duménil and Lévy reinforce this affirmation by asking whether it is more ad hoc to assume that markets are always clearing or to assume that firms lower their production when they observe that their inventories are rising or that their sales are declining. 5 Duménil and Lévy propose a dynamic disequilibrium analysis and a procedural rationality that lie completely within the domain of Post-Keynesianism.

5 Amable et al. (1995) also use the ad hoc critique as a boomerang, showing that, because their microeconomic foundations lack realism, neoclassical authors are being forced to introduce a large number of ad hoc elements, for otherwise their research programme would be completely sterile. 


\section{Pricing \\ 3.I Prices of Production and Cost-plus Pricing}

Since we have immersed ourselves in microeconomics, we might as well stay a little longer. One of the most controversial subjects in heterodox economics is obviously pricing theory. Here, Duménil and Lévy get along well with Sraffians since they essentially adopt the Sraffian or classical idea of prices of production, putting aside labour values like the regulationists have done. The advantage of Duménil and Lévy's approach, at least compared to the earlier Sraffians, is that they do not assume the existence of long-period prices. Instead, they demonstrate that, under certain conditions, randomly set prices will eventually converge toward prices of production. This is the infamous gravitation problem, or the issue of the convergence toward prices of production, that has given many a French economist a headache, economists who are far more competent than me on this question.

The gravitation problem has led to the creation of several models, most notably crossdual models, which will be defined later. A variation on cross-dual models used by some, and especially French, heterodox writers is based on the hypothesis that short-period prices - market prices - are so flexible that they allow for markets to be temporarily in equilibrium. I believe that this variation has been abandoned today because it does not accurately reflect the way firms set prices in industrial markets and service markets. It is this variation that comes closest to the Walrasian approach, and it is the one that Duménil and Lévy (1990) clearly challenged in their addendum to the 1990 Siena conference.

What is left are gravitation models that are distinct from neoclassical theory. In their addendum, Duménil and Lévy (I990) consider that there are two opposite types of convergence models. There are two possible mechanisms to set prices. The first one is put forward by Post-Keynesians and by Boggio (1980, 1992), and is based on the theory of costplus pricing. The simplest version of this theory is the mark-up on variable unit costs ( $\dot{a}$ la Kalecki), while the most advanced is full-cost theory (or normal cost pricing), based on a targeted rate of return (Lanzillotti 1958). The second mechanism for setting prices is that which is defended by Duménil and Lévy and Marxist economists in general, where prices evolve as a function of disequilibria (in quantities) between the supply and demand of goods. This second mechanism is the aforementioned cross-dual dynamics, since discrepancies between the profit rate (normal or realized), or ’prices`, lead to fluctuations in production or production capacity, or squantities`.

As surprising as this may seem, the position of contemporary Sraffians is fairly close to that of Kaleckians. In the past, and based on the works of dominant Sraffians like Garegnani (1983), or Eatwell and Milgate (1983), production prices were associated with quasi-stationary states of equilibria, and long-term classical or normal equilibria with normal capacity utilisation rates (fully adjusted, according to Vianello [1985]). This makes normal output (with a normal utilisation rate) a long-period centre of gravitation. It is this interpretation, uninfluenced by cyclical fluctuations, that Roncaglia (I995) and Arena (1992: 600) have questioned for a long time. 
Contemporary Sraffians, in agreement with Roncaglia and Arena, now maintain that firms can set production prices on the basis of a normal profit rate even when the realized degree of capacity utilization is different from the normal rate. According to Sraffians, prices of production are not necessarily associated with a long-run, classical equilibrium, with a normal realized output, or with a stationary state. In other words, it is not impossible for a Sraffian to conceive of an economy where the realised profit rate is different from the normal level of the uniform profit rate, because prices are set on the basis of the normal degree of capacity utilisation and not on the current degree of capacity utilisation. This is certainly the opinion of Ciccone (1986) as well as of Palumbo and Trezzini (2003). As Roncaglia aptly states (1995: II5),

"existing firms too consider as unit costs, in their assessment of the situation, the sum of variable and fixed unit costs computed not for current output levels, but for a `normal degree of capacity utilization."

Kaleckians, inspired by Kalecki as well as by authors that are closely associated with the Institutionalist school - Andrews (1949), Means or Eichner (who are notably those who are inspired by pricing theories based on full costs) - make precisely the same argument.

There is also common ground between Post-Keynesian theories and new models of cross-dual dynamics. These new convergence models add direct quantity adjustments or other non-linear adjustments (variations on observed disequilibria or the aggregate of observed disequilibria) to classical cross-duality. These come close to Keynesian and PostKeynesian models, even more so when some of the models incorporate characteristics of price determination through cost-plus pricing since the mark-up on costs is the targeted change on the price side. This is not far from Boggio's (1986) full-cost model, who is the main defender of cost-plus convergence models. In his model, observed disequilibria lead to progressive variations in the costing margin, thanks to the modification of the targeted rate of return of the sector considered.

It therefore seems to me that there is nearly a convergence of opinion on this issue. In my opinion, given all that we know about how businesses set prices in the short term (Lanzillotti 1958, Lee 1998), it seems difficult to deny that these prices are set based on the cost-plus procedure. ${ }^{6}$ The fluctuations in the prices of intermediate inputs or in the cost of labour have a direct influence on current prices or on the prices of the next period, as has been shown by Coutts, Godley and Nordhaus (1978).

The question that remains is how to determine the targeted rate of return, or the normal rate of profit, that helps set the mark-up or the costing margin over unit direct costs. Will this rate depend on conditions that only affect the sector in question, or will it depend on the rate of profit realised elsewhere, or again on the profit rate at equilibrium? Because

6 As Downward and Lee (200I) demonstrate, recent inquiries led by Alan Blinder into price setting by US-American firms support the Post-Keynesian point of view. Identical inquiries, with similar results, were then led by several central banks, including the Bank of Canada and the Bank of Sweden. 
of practical considerations, notably the challenges of obtaining the required information, it seems that the third possibility should be omitted while the second possibility is doubtful, except if one considers that competition occurs within holdings and conglomerates, and that they operate in a large number of sectors. As Boggio (I980: 26) states,

"the informations [sic] that the single firms [sic] receives about the ex-post rates of profit prevailing in the rest of the economy are so scanty and imperfect, that its opinion about them must be considered largely independent from their true values."

Recent financial scandals such as the Enron and WorldCom debacles or the even larger Nortel mess in Canada, as well as a number of similar, smaller-scale examples around the world, demonstrate that it is difficult to correctly evaluate the profitability of a firm or industry. In my opinion, the entry and exit of capital has much to do with the growth rate of sales in a sector. This is an eminently observable variable that can serve as an estimate of the profit rate that can potentially be achieved in the sector in question.

It is noteworthy that while the earlier Duménil and Lévy (1990) seem to be very critical of the cost-plus approach, they later seem to adopt a more conciliatory attitude in Duménil and Lévy (1999: 689). Here, although their equations reflect the usual price setting mechanism used by classical authors, they write that

"[i]n equation (I), prices do not depend on production costs (consequently, changing costs have no impact on prices). An alternative, and perhaps better, model would be a mark-up model in which the mark-up rate is adjusted instead of the price. We use equation (I) for simplicity."

Thus, at least in the short run, cost-plus pricing procedures seem acceptable to everyone. Each school has, nevertheless, its own model of long-run adjustment. But in fact, these are just differences in the specific way the problem is formalized. Duménil and Lévy (I993: I86) as much as Post-Keynesians admit that short-run prices are essentially sticky. They are not equilibrium prices because they do not have the goal of equalising current supply and demand. Short-run adjustments are essentially made through quantities, by changing production to adapt to demand, and by involuntary fluctuations in inventories.

\subsection{Full Cost and Fundamentalist Post-Keynesians}

Another source of tension, if we are to believe surveys of Post-Keynesian theory, is due to the Marshallian foundations of US-American Post-Keynesians - the fundamentalist Keynesians à la Weintraub and Davidson. It is true that the aggregate supply curves that they and their successors use seem to reflect conditions of diminishing returns that Kaleckians associate only with a handful of industries or unusual circumstances. However, in the third chapter of Davidson (1972), his most polished work, Davidson shows that in many respects Marshall is closer to authors who advocate cost-plus price setting procedures than he is to modern neoclassical authors. In this chapter, Davidson refers to Marshall's normal profit which he associates with normal profit in Keynes's Treatise and the targeted rate of return 
with normal utilisation rates endorsed by Post-Keynesians from Cambridge. He adopts this price setting theory with enthusiasm.

Another characteristic of Davidson's chapter (1972: 34) is his reference to the fact that, as Renaud du Tertre (2000) showed in his huge $\mathrm{PhD}$ dissertation, the normal rate of return in the Treatise is determined by the current rate of interest on loans and a premium for enterprise, an idea that is also found in the General Theory. This is precisely the contemporary Sraffian theory of the normal profit rate that is defended by authors such as Garegnani (1978), Panico (I985) and Pivetti (1985). This idea was also advanced by Joan Robinson (1952), but she recanted when criticising Garegnani for daring to suggest the same idea! Yet, this conception of a normal rate of return that depends on the interest rate allows one to combine, without mixing them, real and monetary or financial aspects of the economy. We also find this notion of the costing margin being dependent on the (effective) interest rate in Godley (1999), because firms have to be able to cover the financial cost of holding inventories. The advantage of a cost-plus theory is that it allows all these factors to be incorporated.

To conclude this section, I would like to go back to the notion of the labour theory of value. For certain Marxists, this is still a point that cannot be avoided. But these Marxists could be consoled and satisfied with the model put forward by the Sraffian-Keynesian Luigi Pasinetti (I98I). Pasinetti shows that the labour theory of value, if interpreted properly, is a good estimation of the value of commodities. In Pasinetti's model, as long as the profit rate of a vertically-integrated sector is exactly equal to the growth rate in this sector, the price of a consumption good will be exactly proportional to the total of direct, indirect and hyper-indirect labour (the labour necessary to increase capacity at the rate of increase in demand). Pasinetti's model has indirect connections to theories of the firm proposed by Wood (1975) and Eichner (1987). These authors maintain that the targeted rate of profit, or the costing margin, is proportional to the long-run growth rate estimated by the firm. As a result, although every heterodox economist seems to have his or her own pricing theory, these theories have a number of points in common which become entangled with one another. Their differences should not make us lose sight of their similarities. This is particularly the case in microeconomic theories that have often, wrongly, been put in opposition, such as those of Kalecki and Andrews and Brunner. Maybe one day we will be able to say the same about the debates surrounding the determinants of the evolution of targeted rates of return within sectors.

\section{The Kaleckian Model of Growth}

Convergence models are not necessarily just models of price setting. They also cover investment functions, and thus can at the same time be models of growth. This is because, from the classical point of view, adjustment to disequilibria or to an excessive or deficient realised rate of return happens through investment or disinvestment (the entry or exit of entrepreneurs into a sector). An extremely flexible model of growth is the Kaleckian 
growth model. It rests essentially on three equations: a price formation equation, an investment equation that depends on the rate of capacity utilisation, and a saving equation. Modifications to one or another of these three equations allow one to consider the many contributions of one or another of the major schools of heterodox thought, and also to consider the evolution of modern capitalism through different regimes of accumulation. A Keynesian equilibrium condition is assumed; that is, it is assumed that the production period is long enough for production to adjust to demand. ${ }^{7}$

The Kaleckian model of growth is driven by effective demand. To it, however, one can add all kinds of complexities or restrictions. The model was first presented by Alfredo Del Monte (I975), who ironically was a Neapolitan that was only marginally interested in heterodox economics. It has been extremely fruitful as it allowed for a number of concepts and ideas to be formalised within a relatively simple framework. It also allowed for the clarification of certain differences between Post-Keynesian and Marxist theories, while at the same time bringing out their similarities. Finally, in some cases, the model brought about a kind of synthesis by demonstrating how one could go from a Keynesian (shortperiod) situation to a classical (long-period) situation, as is done by Duménil and Lévy (1999). The model can be made as complex as one wants. Variations on this model are almost limitless (see especially Dutt [I990] and Blecker [2002]). In my opinion, the model is highly useful since it is a common reference for all macroeconomic heterodox schools, be they Kaleckian, Sraffian, regulationist, Marxist or classical.

At first glance, the Kaleckian model of growth resembles the Post-Keynesian or Cambridge model of growth of the I950s and I960s. But this resemblance is an illusion. The models of growth à la Kaldor, Pasinetti and Robinson suffered from a crippling defect which was underlined first by Davidson (I972: I24 f.) and also by Marglin (I984: I25) and Vianello (1985). On the one hand, the Cambridge thinkers maintained that short-run adjustments were essentially made by variations in the rate of capacity utilisation. On the other hand, in these authors' models, all of the weight of adjustment was supported by variations in the costing margin by assuming the existence of a capacity utilisation rate equal to its normal value. At no point did these models explain the traverse from the short run (where capacity utilisation diverges from its normal degree) to the long run (where, by definition, utilisation rates go back to their normal level). These models led to numerous debates which I have myself summarised long ago (Lavoie 1987), but which appear to be of low relevance today, even though some of these debates linger still.

\section{I The Issue of the Normal Rate of Capacity Utilisation}

In the Kaleckian model of growth, unlike the old Cambridge models of growth, there is no schizophrenia between the short and long run. Capacity utilisation rates are endogenous as

7 I also believe that more realistic models have to, instead, consider that production and sales diverge most of the time. These models must therefore take into consideration fluctuations in inventories, in accordance with Duménil and Lévy, on the one hand, and Godley on the other. 
much in the short run as they are in the long run. If the utilisation rates go back to their normal level, this move has to be demonstrated within the framework of the model and not by making it an assumption. As I mentioned earlier, the Kaleckian model is at the juncture point of the different strands of macroeconomic heterodox theory. The proof is that many of the contributions to the understanding and extension of the Kaleckian model come from economists who, more often than not, are more properly labeled Marxists or Sraffians, and not Post-Keynesians. In fact, the Marxist Robert Rowthorn (I98I) is the one who truly launched this kind of modeling by incorporating to the Kaleckian model a distinction between blue collar and white collar workers, the possibility of technical progress ${ }^{8}$, a share of endogenous profits, and a discussion of the stability conditions of the model. Simultaneously, and ironically, the Kaleckian model was also developed at M.I.T. by students of Lance Taylor, a structuralist of development. These students included Amitava Dutt and Edward Amadeo.

The first models primarily brought out the existence of two paradoxes that were valid as much in the long run as they were in the short run: the paradox of thrift, well known among Keynesians, and the paradox of costs, where an increase in real wage costs leads to an increase in the realised profit rate for a given technology, due to an acceleration in the growth rate. These models allow economists to break away from a growth barrier, according to which an increase in the growth rate, except in the case of technical progress, is necessarily associated with a decrease in real wages. On this point, Kaleckians and Sraffians are in absolute agreement since contemporary Sraffians reject this growth barrier. Its origins can be found in Joan Robinson's (1956) Accumulation of Capital and in the Sraffian model of production prices with balanced growth (Spaventa I970)

For contemporary Sraffians (Garegnani [1992] included, see also Kurz [1994] and Garegnani and Palumbo [1999]), demand creates its own productive capacity and there is no necessary negative linkage between the rate of accumulation and real wages, precisely because of the flexibility of the productive capacity utilization rates. Contemporary Sraffians therefore attach great importance to the principle of effective demand, which they consider to be relevant both in the short and in the long run. I would assert that the dichotomy established by Carvalho (1984-85), in which Sraffians were only interested in the long period while other Post-Keynesians were mostly interested in the short period, is no longer valid. ${ }^{9}$

The fact that at least some Sraffians are interested in short-run questions became even more evident when, in the I980s, they embarked upon quite exhaustive critiques of Kaleckian models, notably that of Amadeo (I986). The critiques made by Ciccone (1987)

8 Questions about the appearance and distribution of the fruits of technical progress, a subject which regulationists and Schumpeterians have at heart, can be treated in the framework of a Kaleckian model of growth, as Rowthorn (198I), Kurz (199I) and You (1994) show.

9 I have to recognise, however, that the works of certain Sraffians sometimes seem most contradictory, as they wish both to keep the relevance of production prices and to make long-run equilibria immutable. 
and Committeri (1986, 1987) allowed for the clarification of the new Sraffian point of view on this issue. They also advanced the debate by forcing Kaleckians to make a distinction between the utilisation rate anticipated for the current period and the normal utilisation rate (the targeted long-run utilisation rate). These authors, with Auerbach and Skott (1988) and then Park (1995), also started a debate regarding the following question: can we talk about a long-run equilibrium when the equilibrium utilisation rate diverges from what is judged to be the normal rate? This debate is also at the heart of the critiques made by Duménil and Lévy (I993b) against their regulationist colleagues from CEPREMAP (Centre Pour La Recherche Economique Et Ses Applications), who were said to be adopting Keynesian conditions which are valid for short-run analysis but not for studying longrun issues. The debate prompted certain participants to incorporate additional adjustment mechanisms with the objective of forcing realised utilisation rates to converge toward the normal rate (Duménil/Lévy [1999]). But could it be that the normal rate of utilisation is itself endogenous, thus preserving the endogeneity of realised rates of capacity utilisation even in the long run, when the two rates become equal? Some authors give a positive answer to this question (Lavoie I996, 2003).

\subsection{The Issue of the Investment Function}

The Kaleckian model also allowed Marxist economists to voice their own concerns by establishing the possibility of several accumulation regimes, thus demonstrating that the regime corresponding to the paradox of costs could only be one growth regime among others. In this area, it is the article by Bhaduri and Marglin (1990), a leftist Kaleckian and a Marxist, respectively, that had the largest influence. These authors modified the investment function used by Kaleckians by emphasising that the realised rate of profit was in fact a product of three factors: the inverse of the capital to capacity ratio, the realised rate of utilisation and the profit share in the economy which, in a simplified world, is equivalent to the profit margin. From there, Bhaduri and Marglin (1990) demonstrated that if a higher real wage rate can have a positive impact on consumption, it can also have an even greater negative impact on investment. They then established the existence of three different growth regimes which show similarities with those established by regulationists (Bowles/Boyer 1988), notably regimes where increases in real wages slow the economy down, as is feared by some Marxists.

A similar Kaleckian model was simultaneously formalised by the Sraffian Heinz Kurz (I99I). Like Bhaduri and Marglin, Kurz slightly modified the Kaleckian model of growth by adding an investment function that depends on the rate of capacity utilisation and the normal rate of profit; that is, the profit rate that would be realised if capacities were utilised at their normal rate. Kurz, who added a few complexities to the model by introducing indirect labour and productivity considerations, also finds a multitude of growth regimes that can additionally be compared to those of regulationists based on the sharing of productivity gains. Kurz's model was taken up by Olivier Bruno (1999) who, to the quantity dynamics already present, superposed a price dynamics where the variations in costing margins 
depend on disequilibria between supply and demand. Bruno therefore obtains equilibria that are path-dependent. In other words, it is a hysteresis model with multiple equilibria, where the equilibrium effectively achieved depends on the parameters of behaviour during the transition. Other Kaleckian growth models with hysteresis and path dependency have also been formalised, by other means, by Lavoie (1996) and Dutt (1997). ${ }^{\text {Io }}$

\subsection{Class Conflict and Economic Activity}

Other key Marxist ideas have been formalised within the framework of the Kaleckian model of growth. Marxists, at least US-American Marxists, often assert that falling unemployment or an increase in capacity utilisation rates lead to greater bargaining power when wages are negotiated. This can be formalised in the price equation of the Kaleckian model by making the profit margin, or the profit share, an endogenous variable which is non-linear with regard to the capacity utilisation rate. This means that the relationship between the profit share and the capacity utilisation rate eventually becomes negative, which therefore results in a bell-shaped relationship between the profit rate and the utilisation rate seen from the supply side. This was presented by David Gordon (1994, 1997) and is also found in the work of regulationists Bowles and Boyer (1988), whose curves were derived from an analysis of efficiency wages. Once again, these modifications create a multiplicity of cases and complicate the analysis of stability.

More recently Stockhammer (2004) built a Kaleckian model of growth where, following Gordon's hypothesis, a higher unemployment rate leads to a rise in the profit share of firms, and where the accumulation rate is proportional to this profit share. With an exogenous growth rate (the snatural ' growth rate), it allows the author to take an equilibrium rate of unemployment into account, to establish the presence of several different regimes, and to demonstrate that the realized unemployment rate always depends on effective demand despite the presence of a natural growth rate. ${ }^{\text {II }}$

The analysis of power struggle between workers and capitalists brings the question of inflation into these models of growth. Kaleckians as well as US-American Post-Keynesians often favour the notion of conflictual inflation which is built around struggles for income distribution. This can easily be integrated into Kaleckian models of growth (Taylor I990, Cassetti 2002, Lavoie 2003). Of course, the bargaining power of different actors can evolve as a function of demand-related variables such as capacity utilisation rates. Some presentations, such as that of Duménil and Lévy (1999), easily lend themselves to a comparison with the New Keynesian models in the New Consensus (the new neoclassical synthesis), especially if one superposes on these new monetary consensus models a theory of endogenous growth (Lavoie/Kriesler, forthcoming).

IO It is interesting to note that Duménil and Lévy (I990b: 24I) also propose a model subject to 'path dependency،. The equilibria of this model can depend on values taken by the reaction parameters during the transition.

II A recent work by Dutt (2005) shows the diverse mechanisms that could lead to the convergence of the natural growth rate and the demand-driven growth rate. These two rates can be endogenous. 
The latest developments of modern capitalism have brought out another kind of conflict, that between managers (white collar workers) and employees. This is the question of managerialism and of its relationship with financial capitalism, recently highlighted by Duménil and Lévy (2003, ch. 7). The question of changes in relative pay between managers and employees can easily be incorporated into a Kaleckian growth model, as shown recently by Palley (2005), but also by Lavoie (1996b) in a model with a targeted rate of return, even though the paper does not explicitly refer to managerialism.

As emphasised by Cordonnier (2003) in a recent paper presented at the MATISSE seminar on heterodoxies, other characteristics of modern capitalism are the importance of shareholders, changes in the propensity to consume caused by rising fluctuations in the stock market, and the larger proportion of corporate revenues being distributed to households. Cordonnier basically uses the static Kaleckian model to represent these changes and their consequences. Naturally, once again, these could easily be analysed in the framework of the Kaleckian model of growth by modifying and making the saving function more complex (because it depends on the different components of revenue) in order to take interest payments and the class of rentiers into account. One can find similar ideas in the works of Marxist and Post-Keynesian authors, such as Epstein (1994) or Hein and Ochsen (2003).

\section{Integrating Money and Finance Into Macroeconomic Models}

The introduction of monetary factors allows us to move on to what strikes me to be the most important change in the evolution of the different strands of macroeconomic heterodoxy over the past ten years. This concerns the efforts devoted by these different strands to address the question of integrating the real and the financial aspects of macroeconomics. It has been the most challenging question for a number of colleagues for ages, so much so that the expression - the integration of money - seems to be nearly devoid of any useful meaning. But it seems that if heterodox schools have something in common today, it can be found in the multiple attempts to tackle questions of growth and unemployment within theories and formalizations that put much emphasis on monetary and financial phenomena. We could obviously state that this apparent convergence among heterodox schools is the result of the financialisation of our current capitalist system. There is truth in this, but I also think that different heterodox schools of thought have come to the conclusion that, to the best of our abilities, we need to address real and financial problems at the same time. This is both because they are inextricably linked and for reasons of coherence.

In the past, save perhaps a few exceptions, heterodox economists specialised either in the study of real or monetary questions. Even those who were interested in both aspects had trouble formalising direct links between the two. Some of my own work illustrates this failing. As I highlighted earlier, Kaleckian models of growth started to integrate real and financial features only in the I990s. It is quite significant, I believe, that various economists are finding in the works of older scholars elements of monetary economics that had 
remained in the background. Thus, we are now discovering in Joan Robinson's Accumulation of Capital (1956), up to now only recognised as a serious treatise on growth and technical choice, that there are several chapters devoted to an original analysis of monetary theory (Rochon 2005). Similarly, Alfred Eichner (1987), associated especially with studies of the firm and price setting, is now drawing attention for his use of financial flow accounts in his monetary theories. Finally, Stockhammer (2004) brings out elements that have long time been set aside, those being the financial constraint of firms and the propensity of firms to hold large proportions of financial assets instead of holding tangible assets. These were themes addressed by Adrian Wood (1975) from Cambridge in his price-setting studies.

Regulationists like Aglietta et al. (1995), Boyer (2000), Plihon (2002) as well as Passet and du Tertre (2004) have also observed in great detail the changes that characterise modern capitalism. They have sought to explicitly model the role of financial variables in models of growth as well as the financial norms, such as return on equity, which pension funds and mutual funds have attempted to impose upon the managers of non-financial firms. This is also true for Marxists: while they are concerned with the financing of capital accumulation, they also now explicitly formalise certain financial variables. Such is the case for Shaikh (1989) and Duménil and Lévy (2000), whose book is completely devoted to analysing the evolution of financial capitalism. For these authors, the evolution of monetary policy and the evolution of interest rates play a key role in explaining economic cycles. ${ }^{12}$

Hyman Minsky's ideas, which describe Wall Street capitalism and the importance of financial variables in decision making related to real variables, had an enormous influence on all heterodox schools, especially on regulationists and US-American Marxists, and not just on Post-Keynesian authors. Even if there is disagreement about the validity of some of the lessons drawn from his financial instability hypothesis, Minsky nonetheless encouraged a number of heterodox authors, particularly young researchers, to take financial ratios into consideration and to model them when analyzing the evolution of an economy or setting up a macroeconomic model. This is also related to the renewed interest in the works of Joseph Steindl (1952), a once-forgotten Kaleckian who also sought to integrate financial and real variables.

These monetary concerns have also affected Sraffians. Some have taken up the study of monetary theories tackling, as previously mentioned, the relationship between the level of interest rates and the determination of the normal profit rate. Young Sraffians like Park (2002) devote entire articles to adequately formalising the introduction of the banking sector or financial conditions in a model of growth with prices of production. In this area, Peter Skott's study (1989) gave the tone to an entire research program integrating real and financial variables. To do so, he extended Kaldor's (I966) neo-Pasinetti model, who quite remarkably introduced the stock market into a Cambridge growth model.

I2 The convergence toward what could be labeled as Post-Keynesian preoccupations is illustrated by the fact that Post-Keynesians Deprez and Dalendina (1994) criticized Duménil and Lévy precisely because they felt that these authors did not pay enough attention to financial variables. Such a critique could not be made anymore. 
In my opinion, the present efforts devoted to the integration of real and financial variables explain the renewed interest in the works of Wynne Godley, works that I have been familiar with since 1999. Godley and Cripps's book (1983) was a response to the monetarist critiques of Keynesian models in which, with the exception of the works of Tobin and some of his colleagues that were subsequently abandoned, the real and the monetary variables were not integrated well enough. Godley and Cripps's book, despite or perhaps because of its originality (notably by requiring a coherence between stocks and flows and by advocating the building of models based on stock-flow norms and ratios), had almost no impact among heterodox economists. Godley's most recent works like Godley (1999), however, are generating much interest, at least among economists like Anwar Shaikh (Godley/Shaikh 2002) and Lance Taylor (2004).

Godley proposes a coherent accounting framework that allows for the integration of the real and the monetary variables. This is his transactions-flow matrix, accompanied by a balance sheet matrix, which could already be found in Godley and Cripps (1983). The budget constraint of each sector takes revenue and expense flows, linked to real activities, into account, but it also must take into consideration changes in the acquired assets and the incurred debts. All financial assets must have explicit counterparts. The accounting framework proposed by Godley allows one to be reassured that nothing has been left out and that all data are coherent. ${ }^{13}$ Moreover, as Taylor (2004: 2) confirms, this accounting framework and the restrictions imposed by the coherence of stocks and flows

»remove many degrees of freedom from possible configurations of patterns of payments at the macro level, making tractable the task of constructing theories to scloser the accounts into complete models."

In fact, Anwar Shaikh considers that this accounting framework, that can be modified at will to simplify or to integrate more pressing questions, could provide a common base for all heterodox macroeconomic theoreticians. It would constitute the alternative to the principle of constrained maximisation in neoclassical theory. This is also the opinion of other New School University economists since, in their recent presentation synthesising heterodox models of growth, Foley and Taylor (2004) adopt a slightly modified transactions matrix.

To this accounting framework, Godley's models add Post-Keynesian behavioural equations. They also add linearised portfolio equations à la Tobin, with different adding-up constraints, which allow for the real and the monetary variables to be integrated by dealing in a consistent way with both the banking system and the central bank as well as the production and inventory problems of the firm. The framework put forward by Godley and the portfolio equations he uses very much allow for money to be considered both as a flow, as circuitists would like, and as a stock, as Keynes recommended. Godley's accounting framework guarantees the coherence between stocks and flows (an objective held by neoclassical authors as well), allowing heterodox authors to construct alternative and

I3 I notice regularly as a journal referee that these basic accounting relationships are not always respected. 
consistent macroeconomic models through the introduction of Post-Keynesian or Marxist behavioural equations.

The extension of this method to the open economy sphere also allows for the rediscovery and validation of certain heterodox assertions. This includes the compensation thesis that was supported by Bank of France economists in the I970s (Berger 1972). According to this thesis, it is possible to control the interest rates in an open economy with fixed exchange rates since foreign reserves arising from balance-of-payment surpluses are compensated by the reduction in other items of the central bank balance sheet, as a result of the normal behaviour of economic agents (Godley/Lavoie 2005-06).

Godley's accounting framework is very much flexible. ${ }^{I 4}$ Those able to use it for simulations can model problems of debt, equity capital, banks or production firms as they like. They can also model problems of market speculation by adding adequate equations for household behaviour or financial institutions. Dos Santos and Zezza (2004), for example, do this by departing from the basic model suggested by Lavoie and Godley (2OOI-O2) which includes only households, a simplified banking sector, and firms that finance their investments by issuing equities or by borrowing from banks. They superpose a government sector, a central bank and equations related to productivity and inflation.

\section{Conclusion}

The present text only tackled four issues in economics. I could have also dealt with the works on technical progress that provide a direct link between regulationists (Boyer/Petit I988) and Post-Keynesians (McCombie/Thirlwall 1994). I apologise once again for being partial in my choice of topics. To answer the question I asked at the beginning, yes, I believe that heterodox theories have a number of things in common. Beyond their methodology and their conception of rationality, heterodox authors share a pricing theory that has a number of similarities. They all draw on a very flexible tool - the Kaleckian model of growth. Founded on the principle of effective demand, this model can be used to study a very large number of macroeconomic questions by introducing a variety of theories and hypotheses. Finally, I believe that at this moment, there is an extraordinary convergence among heterodox macroeconomists who are trying, through diverse means, to incorporate financial and monetary questions in the framework of models dealing with real variables. Moreover, a window of opportunity has now opened for heterodox theories since the intervention procedures of central banks are fully consistent with the monetary theories that have been advocated by heterodox writers for more than forty years. Heterodox economists certainly have the means and the models to criticise and modify the New Consensus model developed by New Keynesians and researchers of central banks.

I4 It can be cumbersome however. Taylor (2004) seems to suggest the use of financial flow and balance sheet matrices as a reminder only, relying on reduced form equations instead of entire sets of equations. 
Despite the diversity of heterodox economics, I believe we have to recognise the convergences that have been outlined above. I attribute these convergences to the reciprocal influence that the various schools of thought have had on one another. Despite the centrifugal forces which are related to the hyper-specialisation that threatens us all, heterodoxies are not entirely divided. Bridges exist between the different schools, and there are researchers who are ready to cross them. Although it might be wishful thinking, it seems to me that with respect to the Post-Keynesian school, the once dominant established versions (to use Richard Arena's expression [1992]) are now losing ground to the dissident versions which are less rigid and more eclectic.

I would like to conclude by citing Luigi Pasinetti (I990: I6). Pasinetti was marveled by the brimming ideas among heterodox economists at Cambridge, and regretted that none of them ever tried to propose a synthesis of their common comprehension of economics:

"The main wrong that we could do them would be to adopt the easier attitude that we should follow them closely, as individuals, focusing on the singularity of their conceptions, the idiosyncrasies of their behaviour and the emotionalism of their reactions. This would not favour the development of the seminal ideas that they left us [.] [...] It seems that it is exactly this kind of behaviour we have to be wary of if we want to avoid rigidity or mental blocks precisely when flexibility and openness of spirit are indispensable«.

\section{References}

Aglietta, Michel/Coudert, Virginie/Mojon, Benoit (1995): Actifs patrimoniaux, crédits et économie réelle, Cahiers économiques et monétaires, Banque de France

Amable, Bruno/Boyer, Robert/Lordon, Frédéric (1995): L’ad hoc en économie: la paile et la poutre, in: d'Autume, Antoine/Cartelier, Jean (eds.), Léconomie devient-elle une science dure?, Paris: Économica, pp. 257-290

Amadeo, Edward J. (1986): The Role of Capacity Utilization in Long-period Analysis, in: Political Economy, Vol. 2, No. 2, pp. I47-I85

Andreff, Wladimir (1996): Hétérodoxie ou critique en économie?, in: Économies et Sociétés, No. 9, pp. 239-252

Andrews, Philip W. S. (1949): A Reconsideration of the Theory of the Individual Business, in: Oxford Economic Papers, Vol. I, No. I, pp. 54-89

Arena, Richard (1992): Une synthèse entre post-keynésiens et néo-ricardiens est-elle encore possible?, in: L'Actualité économique, Vol. 68, No. 4, pp. 587-606

Auerbach, Paul/Skott, Peter (1988): Concentration, Competition and Distribution - A Critique of Monopoly Capital, in: International Review of Applied Economics, Vol. 2, No. I, pp. $42-6 \mathrm{I}$

Berger, Pierre (1972): Rapports entre l'évolution de la balance des paiements et l'évolution de la liquidité interne, in: de Lattre, André/Berger, Pierre (eds.), Monnaie et balance de paiements, Paris: Armand Colin, pp. 89-IIO 
Bhaduri, Amit/Marglin, Stephen A. (1990): Unemployment and the Real Wage: The Economic Basis For Contesting Political Ideologies, in: Cambridge Journal of Economics, Vol. I4, No. 4, pp. 375-393

Blecker, Robert (2002): Distribution, Demand and Growth in Neo-Kaleckian Macro-models, in: Setterfield, Mark (ed.), The Economics of Demand-Led Growth: Challenging the Supply-side Vision of the Long-run, Cheltenham: Edward Elgar, pp. I29-152

Boggio, Luciano (1980): Full Cost and SSraffa Pricesı: Equilibrium and Stability in a System With Fixed Capital, in: Monte dei Paschi di Siena Economic Notes, Vol. 9, No. I, pp. 3-33

Boggio, Luciano (1986): Stability of Production Prices in a Model of General Dependence, in: Semmler, Willi (ed.), Competition, Instability, and Nonlinear Cycles, New York: Springer Verlag, pp. 83-II4

Boggio, Luciano (1992): Production Prices and Dynamic Stability: Results and Open Questions, in: Manchester School of Economic and Social Studies, Vol. 6o, No. 3, pp. 264-294

Bowles, Sam/Boyer, Robert (1988): Labor Discipline and Aggregate Demand: a Macroeconomic Model, in: American Economic Review, Vol. 78, No. 2, pp. 395-400

Boyer, Robert (2000): Is a Finance-led Regime a Viable Alternative to Fordism?, in: Economy and Society, Vol. 29, No. I, pp. III-I45

Boyer, Robert/Petit, Pascal (1988): The Cumulative Growth Model Revisited, in: Political Economy: Studies in the Surplus Approach, Vol. 4, No. I, pp. 23-43

Bruno, Olivier (1999): Long-run Positions and Short-run Dynamics in a Classical Growth Model, in: Metroeconomica, Vol. 50, No. I, pp. II9-I37

Carvalho, Fernando (1984-85): Alternative Analyses of Short and Long Run in Post Keynesian Economics, in: Journal of Post Keynesian Economics, Vol. 7, No. 2, pp. 2I4-2I4

Ciccone, Roberto (1986): Accumulation and Capacity Utilization: Some Critical Considerations on Joan Robinson's Theory of Distribution, in: Political Economy, Vol. 2, No. I, pp. $17-36$

Ciccone, Roberto (1987): Accumulation, Capacity Utilization and Distribution: A Reply, in: Political Economy, Vol. 3, No. I, pp. 97-III

Cassetti, Mario (2002): Conflict, Inflation, Distribution and Terms of Trade in the Kaleckian Model, in: Setterfield, Mark (ed.), The Economics of Demand-Led Growth: Challenging the Supply-side Vision of the Long-run, Cheltenham: Edward Elgar, pp. I89-2II

Committeri, Marco (1986): Some Comments on Recent Contributions on Capital Accumulation, Income Distribution and Capacity Utilization, in: Political Economy: Studies in the Surplus Approach, Vol. 2, No. 2, pp. 16I-I86

Committeri, Marco (1987): Capital Utilization, Distribution and Accumulation: A Rejoinder to Amadeo, in: Political Economy: Studies in the Surplus Approach, Vol. 3, No. I, pp. 9I-95

Cordonnier, Laurent (2003): Le profit sans l'accumulation: la recette du capitalisme gouverné par la finance, Séminaire MATISSE Hétérodoxies, mai 2003

Coutts, Ken/Godley, Wynne/Nordhaus, William (1978): Industrial Pricing in the United Kingdom, Cambridge: Cambridge University Press

Davidson, Paul (1972): Money and the Real World, London: Macmillan 
Davidson, Paul (198I): Post Keynesian Economics: Solving the Crisis in Economic Theory, in: The Public Interest, pp. 15I-I73

Davidson, Paul (1982): International Money and the Real World, London: Macmillan

Davidson, Paul (1994): Post Keynesian Macroeconomic Theory, Aldershot: Edward Elgar

Davidson, Paul (2003-04): Setting the Record Straight on. A History of Post Keynesian Economics, in: Journal of Post Keynesian Economics, Vol. 26, No. 2, pp. 245-272

Davidson, Paul (2005): Responses to Lavoie, King, and Dow on What Post Keynesianism is and Who is a Post Keynesian, in: Journal of Post Keynesian Economics, Vol. 27, No. 3, pp. 393-409

Del Monte, Alfredo (I975): Grado di monopolio e sviluppo economico, in: Rivista Internazionale di Scienze Sociali, Vol. 83, No. 3, pp. 26I-283

Deprez, Johan/Dalendina, Patrick Dolenc (1994): The Monetary Determinants of (In)stability: Some Contrasts of Duménil/Lévy and the Post Keynesians, in: Review of Radical Political Economics, Vol. 26, No. 3, pp. 66-75

Dos Santos, Claudio H./ Zezza, Gennaro (2004): The Role of Monetary Policy in Post-Keynesian stock-flow Consistent Growth Models, in: Lavoie, Marc/Seccareccia, Mario (eds.), Central Banking in the Modern World: Alternative Perspectives, Cheltenham: Edward Elgar, pp. 183-210

Downward, Paul/Lee, Frederic S. (200I): Post Keynesian Pricing Theory Reconfirmed? A Critical Review of Asking About Prices, in: Journal of Post Keynesian Economics, Vol. 23, No. 3, pp. 465-483

Duménil, Gérard/Lévy, Dominique (1990): Convergence to Long-period Positions: An Addendum, in: Political Economy: Studies in the Surplus Approach, Vol. 6, No. I-2, pp. $265-278$

Duménil, Gérard/Lévy, Dominique (I990b): La concurrence classique à la croisée des chemins, in: Cartelier, Jean (ed.), La formation des grandeurs économiques, Paris: Presses Universitaires de France, pp. 209-262

Duménil, Gérard/Lévy, Dominique (1993): The Economics of the Profit Rate, Aldershot: Edward Elgar

Duménil, Gérard/Lévy, Dominique (1993b): Les régulationnistes pouvaient-ils apprendre davantage des classiques?, in: Économies et Sociétés, Vol. 24, No. 6, pp. II7-I55

Duménil, Gérard/Lévy, Dominique (1995): Vrais et faux dilemmes, in: Recherches économiques de Louvain, Vol. 6I, No. 3, pp. 359-394

Duménil, Gérard/Lévy, Dominique (1999): Being Keynesian in the Short Term and Classical in the Long Term: The Traverse to Classical Long-term Equilibrium, in: The Manchester School, Vol. 67, No. 6, pp. 684-716

Duménil, Gérard/Lévy, Dominique (2000): Crise et sortie de crise: Ordre et désordres néolibéraux, Paris: Presses Universitaires de France

Duménil, Gérard/Lévy, Dominique (2003): Économie marxiste du capitalisme, Paris: La Découverte

Du Tertre, Renaud (2000): La formation des prix dans l'économie de Keynes: Incertitude et prévision, PhD dissertation, Université de Paris X-Nanterre 
Dutt, Amitava K. (1990): Growth, Distribution and Uneven Development, Cambridge: Cambridge University Press

Dutt, Amitava K. (1997): Equilibrium, Path Dependence and Hysteresis in Post-Keynesian Models, in: Arestis, Philip/Palma, Gabriel/Sawyer, Malcolm (eds.), Markets, Unemployment and Economic Policy: Essays in Honour of Geoff Harcourt, Vol. 2, London: Routledge, pp. 238-253

Dutt, Amitava K. (2005): Aggregate Demand, Aggregate Supply and Economic Growth, paper presented at the conference of the Eastern Economic Association, New York, March 2005 Eatwell, John/Milgate, Murray (eds.) (1983): Keynes's Economics and the Theory of Value and Distribution, Oxford: Oxford University Press

Eichner, Alfred S. (1987): The Macrodynamics of Advanced Market Economies, Armonk: M.E. Sharpe

Epstein, Gerald (1994): A political Economy Model of Comparative Central Banking, in: Dymski, Gary/ Pollin, Robert (eds.), New Perspectives in Monetary Macroeconomics: Explorations in the Tradition of Hyman P. Minsky, Ann Arbor: University of Michigan Press, pp. 23I-277

Foley, Duncan/Taylor, Lance (2004): A Heterodox Growth and Distribution Model, paper presented at the Growth and Distribution conference at the University of Pisa

Garegnani, Pierangelo (1978): Notes on Consumption, Investment and Effective Demand: II, in: Cambridge Journal of Economics, Vol. 3, No. I, 63-82

Garegnani, Pierangelo (1983): Two Routes to Effective Demand, in: Kregel, Jan (ed.), Distribution, Effective Demand and International Economic Relations, London: Macmillan, pp.69-80

Garegnani, Pierangelo (1992): Some Notes for an Analysis of Accumulation, in: Halevi, Joseph/Laibman, David/Nell, Edward J. (eds.), Beyond the Steady State: A Revival of Growth Theory, London: Macmillan, pp. 47-7I

Garegnani, Pierangelo/Palumbo, Antonella (1999): Accumulation of Capital, in: Kurz, Heinz

D./Salvadori, Neri (eds.), The Elgar Companion to Classical Economics, Vol. I, Cheltenham: Edward Elgar, pp. Io-I8

Godley, Wynne (1999): Money and Credit in a Keynesian Model of Income Determination, in: Cambridge Journal of Economics, Vol. 23, No. 4, pp. 393-4II

Godley, Wynne/Cripps, Francis (1983): Macroeconomics, London: Fontana Books

Godley, Wynne/Lavoie, Marc (2005-06): Comprehensive Accounting in Simple Open Economy Macroeconomics With Endogenous Sterilization or Flexible Exchange Rates, in: Journal of Post Keynesian Economics, Vol. 28, No. 2, pp. 24I-276

Godley, Wynne/Shaikh, Anwar (2002): An Important Inconsistency at the Heart of the Standard Macroeconomic Model, in: Journal of Post Keynesian Economics, Vol. 24, No. 3, pp. 423-44I

Gordon, David M. (1994): Putting Heterodox Macro to the Test: Comparing Post-Keynesian, Marxian, and Social Structuralist Macroeconometric Models of the Post-war US Economy, in: Glick, Mark A. (ed.), Competition, Technology and Money: Classical and Post-Keynesian Perspectives, Aldershot: Edward Elgar, pp. I43-I85 
Gordon, David M. (1997): Must We Save Our Way Out of Stagnation? The Investment-savings Relationship Revisited, in: Pollin, Robert (ed.), The Macroeconomics of Saving, Finance and Investment, Ann Harbor: Michigan University Press, pp. 95-160

Gowdy, John M./ Mayumi, Kozo (200I): Reformulating the Foundations of Consumer Choice Theory and Environmental Valuation, in: Ecological Economics, Vol. 39, No. 2, pp. 223-237

Hamouda, Omar F./Harcourt, Geoffrey C. (I988): Post Keynesianism: From Criticism to Coherence?, in: Bulletin of Economic Research, Vol. 40, No. I, pp. I-33

Hein, Eckhard/Ochsen, Carsten (2003): Regimes of Interest Rates, Income Shares, Savings and Investment: A Kaleckian Model and Empirical Estimations for Some Advanced OECD Economies, in: Metroeconomica, Vol. 54, No. 4, pp. 404-433

Kaldor, Nicholas (1966): Marginal Productivity and the Macro-economic Theories of Distribution, in: Review of Economic Studies, Vol. 33, No. Io, pp. 309-319

King, John E. (1995): Conversations with Post Keynesians, London: Macmillan

King, John E. (2002): A History of Post Keynesian Economics Since 1936, Cheltenham: Edward Elgar

Kurz, Heinz D. (199I): Technical Change, Growth and Distribution: A Steady State Approach to Unsteady Growth on Kaldorian Lines, in: Nell, Edward J./Semmler, Willi (eds.), Nicholas Kaldor and Mainstream Economics, London, Macmillan, pp. 42I-448

Kurz, Heinz D. (1994): Growth and Distribution, in: Review of Political Economy, Vol. 6, No. 4, 393-420

Lanzillotti, Robert F. (1958): Pricing Objectives in Large Companies, in: American Economic Review, Vol. 48, No. 5, pp. 92I-940

Lavoie, Marc (1987): Macroéconomie: théorie et controverses postkeynésiennes, Paris: Dunod

Lavoie, Marc (1992): Foundations of Post-Keynesian Economic Analysis, Aldershot: Edward Elgar

Lavoie, Marc (I992b): Towards a New Research Programme For Post-Keynesianism and NeoRicardianism, in: Review of Political Economy, Vol. 4, No. I, pp. 37-78

Lavoie, Marc (1996): Traverse, Hysteresis, and Normal Rates of Capacity Utilization in Kaleckian Models of Growth and Distribution, in: Review of Radical Political Economics, Vol. 28, No. 4, pp. II3-I47

Lavoie, Marc (1996b): Unproductive Outlays and Capital Accumulation With Target-return Pricing, in: Review of Social Economy, Vol. 54, No. 3, pp. 303-32I

Lavoie, Marc (2003): Kaleckian Effective Demand and Sraffian Normal Prices: Towards a Reconciliation, in: Review of Political Economy, Vol. I5, No. I, pp. 53-74

Lavoie, Marc (2005): Post-Keynesian Consumer Choice Theory For the Economics of Sustainable Forest Management, in: Kant, Shashi/Berry, R. Albert (eds.), Economics, Sustainability and Natural Resources: Economics of Sustainable Forest Management, Dordrecht: Springer, pp. 67-90

Lavoie, Marc (2006): Introduction to Post-Keynesian Economics, London: Palgrave/ Macmillan 
Lavoie, Marc/Godley, Wynne (200I-02): Kaleckian Models of Growth in a Coherent Stockflow Monetary Framework: A Kaldorian View, in: Journal of Post Keynesian Economics, Vol. 24, No. 2, pp. 277-3I2

Lavoie, Marc/Kriesler, Peter (forthcoming): The Duménil and Lévy Macro Model and the New Keynesian Consensus, in: Review of Radical Political Economics

Lawson, Tony (1997): Economics and Reality, London: Routledge

Lee, Frederic S. (1998): Post Keynesian Price Theory, Cambridge: Cambridge University Press Maki, Uskali (1989): On the Problem of Realism in Economics, in: Ricerche Economiche, Vol. 43, No. I-2, pp. 176-198

Marglin, Stephen A. (1984): Growth, Distribution, and Inflation: A Centennial Synthesis, in: Cambridge Journal of Economics, Vol. 8, No. 2, June, pp. II5-I44

McCombie, John S.L./Thirlwall, Anthony (1994): Economic Growth and the Balance-ofPayments Constraint, New York: St. Martin's Press

Panico, Carlo (1985): Market Forces and the Relation Between the Rates of Interest and Profits, in: Contributions to Political Economy, Vol. 4, No. I, pp. 37-60

Palley, Tom (2005): Class Conflict and the Cambridge Theory of Distribution, in: Gibson, Bill (ed.), Joan Robinson's Economics: A Centennial Celebration, Cheltenham: Edward Elgar, pp. 203-224

Palumbo, Antonella/Trezzini, Attilio (2003): Growth Without Normal Utilization, in: European Journal of the History of Economic Thought, Vol. Io, No. I, I09-I35

Park, Man-Seop (I995): A Note on the Kalecki-Steindl Steady-state Approach to Growth and Income Distribution, in: The Manchester School, Vol. 58, No. 3, pp. 297-310

Park, Man-Seop (2002): Growth and Income Distribution in a Credit-money Economy: Introducing a Banking Sector Into the Linear Production Model, in: Cambridge Journal of Economics, Vol. 26, No. 5, pp. 585-612

Pasinetti, Luigi L. (198I): Structural Change and Economic Growth, Cambridge: Cambridge University Press

Pasinetti, Luigi L. (1990) : A la mémoire de Piero Sraffa, économiste italien à Cambridge, in: Arena, Richard (ed.), Sraffa trente ans après, Paris: Presses Universitaires de France, pp. 3-18

Pasinetti, Luigi L. (2005): The Cambridge School of Keynesian Economics, in: Cambridge Journal of Economics, Vol. 29, No. 6, pp. 837-848

Passet, Olivier/Du Tertre, Renaud (2004): La rentabilité de l'entreprise de l'euphorie boursière à la crise financière, MATISSE Hétérodoxies Workshop, January

Pivetti, Massimo (1985): On the Monetary Explanation of Distribution, in: Political Economy, Vol. I, No. 2, pp. 73-IO3

Plihon, Dominique (2002): Rentabilité et risque dans le nouveau régime de croissance, Paris: La Documentation française

Robinson, Joan (1952): The Rate of Interest and Other Essays, London: Macmillan Robinson, Joan (1956): The Accumulation of Capital, London: Macmillan Rochon, Louis-Philippe (2005): Robinson on Credit, Money and Finance, in: Gibson, Bill (ed.), Joan Robinson's Economics: A Centennial Celebration, Cheltenham: Edward Elgar, pp. 267-282 
Roncaglia, Alessandro (1995): On the Compatibility Between Keynes's and Sraffa's Viewpoints on Output Levels, in: Harcourt, Geoffrey/Roncaglia, Alessandro/Rowley, Robin (eds.), Income and Employment in Theory and Practice, New York: St. Martin's Press, pp. III-I25

Rowthorn, Robert E. (198I): Demand, Real Wages and Economic Growth, in: Thames Papers in Political Economy, London: Thames Polytechnic, pp. I-39. Also published in: Studi Economici, No. 18, 1982, pp. 3-54

Setterfield, Mark (2003): What is Analytical Political Economy?, in: International Journal of Political Economy, Vol. 33, No. 2, 4-16

Shaikh, Anwar (1989): Accumulation, Finance and Effective Demand in Marx, Keynes and Kalecki, in: Semmler, Willi (ed.), Financial Dynamics and Business Cycles: New Perspectives, Armonk: M.E. Sharpe, pp. 65-86

Skott, Peter (1989): Conflict and Effective Demand in Economic Growth, Cambridge, Cambridge University Press

Spaventa, Luigi (1970): Rate of Profit, Rate of Growth, and Capital Intensity in a Simple Production Model, in: Oxford Economic Papers, Vol. 22, No. 2, pp. 129-I47

Steindl, Joseph (1952): Maturity and Stagnation in American Capitalism, Oxford: Blackwell

Stockhammer, Engelbert (2004): The Rise of Unemployment in Europe: A Keynesian Approach, Cheltenham: Edward Elgar

Taylor, Lance (1990): Real and Money Wages, Output and Inflation in the Semi-industrialized World, in: Economica, Vol. 57, No. 227, pp. 329-353

Taylor, Lance (2004): Reconstructing Macroeconomics: Structuralist Proposals and Critiques of the Mainstream, Cambridge: Harvard University Press

Vianello, Ferdinando (1985): The Pace of Accumulation, in: Political Economy, Vol. I, No. I, $69-87$

Wood, Adrian (1975): A Theory of Profits, Cambridge: Cambridge University Press

You, Jong-Il (1994): Macroeconomic Structure, Endogenous Technical Change and Growth, in: Cambridge Journal of Economics, Vol. I8, No. 2, pp. 213-233 